\title{
A Invenção do Ressentimento no Século XIX e os Desafios da Psicologia Social no Século XXI
}

The invention of resentment in the XIX century and the challenges of Social Psychology in the XXI century
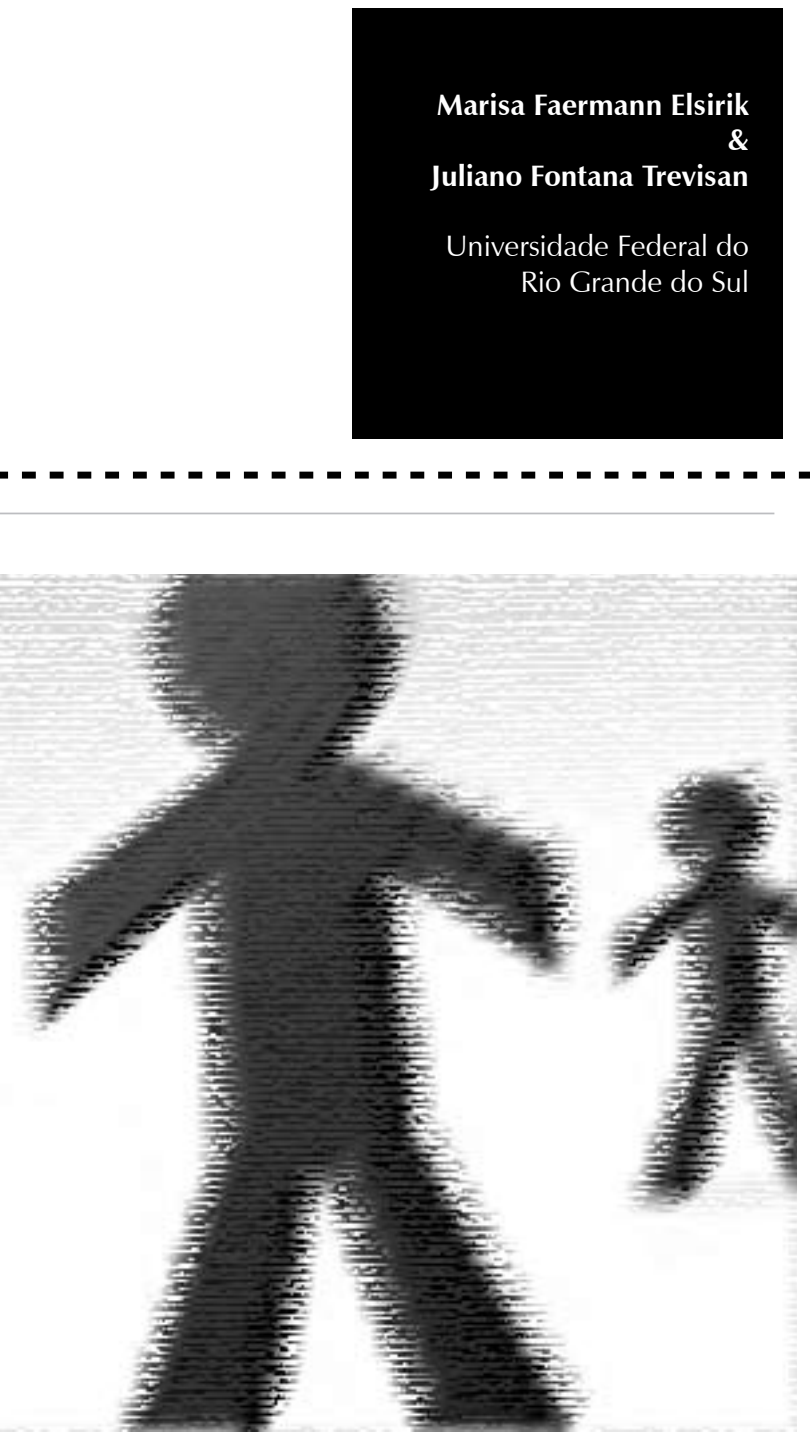
Resumo: Vivemos, na aurora do século XXI, sob os efeitos da profusão de discursos - científicos ou não - que ressaltam cada vez mais uma separação entre o social e o individual. O preocupar-se cada vez mais consigo mesmo em detrimento do social é um movimento que teria se acentuado durante o século XIX. Para além do caráter verdadeiro ou falso contido nessa evidência, temos por objetivo, ao refletir sobre o conceito de ressentimento, pensar sobre as condições históricas que favoreceram a emergência desse discurso, desnudando um social (ou seriam outros sociais?) que nunca se separou do pessoal, mas que nem sempre pode ser visualizado. Esse outro social, entretanto, nos coloca outros desafios para compreender o homem e sua existência.

Palavras-chave: Psicologia social. Nietzsche, Friedrich Wilhelm, 1844-1900. Século XIX. Ressentimento.

\begin{abstract}
We are living in the beginning of the XXI century under the effects of a profusion of discourses - scientific or not - that emphasize more and more a division between the social and the individual aspects. The fact that people get increasingly self-centered to the detriment of the social aspect is a movement that could has been stressed during the XIX century. Beyond the true or false characteristics of this evidence, it is our aim to consider the historical conditions that favour the emergence of this discourse in our reflection on the concept of resentment, showing a social aspect (or would it be other social aspects?) that have never been separated from the personal aspects, but that cannot always be visualized. This evidence, however, gives us other challenges to conceive human beings and their existence.
\end{abstract}

Keywords: Social Psychology. Nietzsche, Friedrich Wilhelm, 1844-1900. XIX century. Resentment.

\title{
Século XIX:
}

\section{a invenção do ressentimento}

Trabalhar com Psicologia social corresponde a atuar em lugares públicos, empresas, grupos, penitenciárias, asilos, creches, comunidades, hospitais psiquiátricos, hospitais gerais, albergues? Como trabalhar na clínica de atendimento individual com uma certa Psicologia social que parece muito voltada, embora não limitada, a contextos mais amplos?

A Psicologia social e a clínica de atendimento individual nunca tiveram uma relação muito amistosa. Os trabalhos e as intervenções nesse campo geralmente incluem um público desfavorecido financeiramente (os pobres) ou que sofre algum tipo de violência, preconceito ou marginalização. Igualmente, os estágios oferecidos por professores que trabalham com Psicologia social muitas vezes acabam se restringindo a espaços institucionais como escolas, postos de saúde, empresas, etc. Por que essa escassez de práticas que unam clínica de atendimento individual e Psicologia social? Que condições sociohistóricas propiciaram essa cisão?

Nietzsche, no livro Genealogia da moral (Nietzsche, 1998), nos apresenta o ressentimento como um sintoma que atinge seu auge no século XIX. Para além de considerá-lo um sintoma social (o que já seria de grande valia para nossos objetivos neste trabalho), o conceito de ressentimento talvez nos possibilite um outro olhar sobre o sofrimento humano: um olhar social.

Logo, uma questão se impõe: Quais as condições históricas de surgimento do ressentimento no século XIX e no que esse afeto pode nos auxiliar na construção de 
"A minha criada é uma aldeã velha, ruim por estupidez, e, além disso, cheira sempre $\mathrm{mal}^{\prime \prime}$

Dostoiévski um outro olhar social sobre o sofrimento que encontramos na clínica de atendimento individual? Dito de outra forma, poderíamos perguntar: Em que medida o conceito de ressentimento pode nos ser útil para pensarmos sobre a subjetividade hoje?

Utilizaremos o livro Assim Falou Zaratustra (Nietzsche, 2003) e Memórias do Subsolo (Dostoiévski, 2000) ${ }^{1}$ como nosso campo de análise, pois essas duas obras são produções do século XIX (século do nascimento do ressentimento). Enquanto aquele nos apresenta sete valores que são sete pilares de uma "moral do ressentimento", este apresenta um personagem ressentido ao extremo. Além desses, tomaremos como parceiro o livro História da Vida Privada IV (Perrot, 1991) um livro denso sobre esse século que estamos abordando.

Nietzsche escreve a um amigo sobre suas impressões do livro Memórias do Subsolo (Dostoiévski, 2000): "A voz do sangue (como denominá-lo de outro modo?) fez-se ouvir de imediato e minha alegria não teve limites". Há ainda outros comentários de Nietzsche sobre o próprio Dostoiévski, considerando-o o único psicólogo com o qual teve algo a aprender. Jamais um livro tratou de forma tão séria - e às vezes até nauseante - a questão do ressentimento como o MS. Sem dúvida, quando Nietzsche chama Dostoiévski de psicólogo, está fazendo um flerte com esse tema tão caro a si próprio em suas últimas obras, em especial a primeira e a segunda dissertações do livro Genealogia da moral (Nietzsche, 1998).

\section{Memórias do subsolo no século XIX}

MS é uma obra literária, e, como tal, é um arquivo histórico sobre um século que tem como centro gravitacional a família. Paradoxalmente, seu personagem central é um sujeito que vive sozinho e que assim se define:

... quem, afinal, sou eu, vou responder: sou um assessor-colegial (posto mediano da administração civil, no regime czarista. N. do T.). Fiz parte do funcionalismo a fim de ter algo para comer (unicamente para isso), e quando, no ano passado, um dos meus parentes afastados me deixou seis mil rublos em seu testamento, aposentei-me imediatamente e passei a viver neste meu cantinho. Já antes disso vivi aqui, mas agora me instalei nele. (...) A minha criada é uma aldeã velha, ruim por estupidez, e, além disso, cheira sempre mal. (Dostoiévski, 2000, pp.17-18)

Cabe salientar que essa apresentação se encontra no primeiro capítulo do MS, que se divide em dois: $O$ subsolo e $A$ propósito da neve molhada. E é assim, portanto, que o personagem se apresenta aos seus leitores, não só a partir desse fragmento, mas também basicamente durante todo o primeiro capítulo, marcado por um monólogo extremamente provocativo entre autor e leitor, com toques refinados de cinismo e ironia (estilos característicos desse século).

A primeira parte do MS - O subsolo caracteriza-se também por um escárnio violento contra a moral da época. Devemos ter em mente - e voltaremos a esse ponto mais adiante, ao abordar esse capítulo - que o século XIX é o momento da representação pública e de uma vida familiar privatizada até a raiz, um teatro dentro e fora de casa. Verifica-se, também, uma cisão entre público e privado sem precedentes na História. Uma vida de rituais entra em ação, e cada qual (pai, mãe, filho, etc.) passa a representar um personagem do qual são esperados alguns comportamentos. É o triunfo da família no início do século, e do indivíduo no final dele. Influenciado por essa moral, o personagem central do livro debate-se em um monólogo 
"Por mais lamentável que fosse o amontoamento dos membros da família em um acanhado reduto, a moral não era afetada.

Vivi ali e jamais ouvi murmurarem o menor escândalo. Uma vida ativa, hábitos piedosos, e um pai e uma mãe austeros, eram coisas que nada permitiam ao relaxamento dos costumes"

Perrot infinito no primeiro capítulo. Em um século marcado pelas certezas das regras do jogo e pelos movimentos possíveis de seus jogadores, esse personagem coloca pontos de interrogação nas mais óbvias e aparentes verdades. "Mas, em primeiro lugar, quando foi que aconteceu ao homem, em todos esses milênios, agir unicamente em prol de sua própria vantagem?" (Dostoiévski, 2000, p. 33). Ou então, duvidar das leis da natureza e do $2+2=4$.

Ainda nesse primeiro capítulo, vemos o personagem disparar suas flechas contra o alvo da consciência. Esse é um dos pontos importantes, pois mostra o desenvolvimento anômalo da consciência em detrimento do corpo, de seus impulsos e instintos. Um remoer incessante e frenético de idéias e pensamentos diversos agita a consciência, que, excitada ao extremo, segrega entre seus produtos o ressentimento (um envenenamento dispéptico que se apresenta sob várias formas, entre elas o ódio, o desejo de vingança e de volta no tempo para "corrigir" algo que deu "errado", a raiva, etc.).

Portanto, temos um personagem que debocha o tempo inteiro de uma moral da aparência e da falsidade. Ao mesmo tempo, ele está ligado a essa moral de modo decisivo a partir do ressentimento, o que lhe permite negá-la, mas não superá-la. A moral não pode ser esquecida por ele, e volta sempre à sua consciência com uma intensidade assustadora.

A consciência é um dos principais aliados da moral do século XIX. Executa-se o sujeito a partir da culpa e da má consciência quando não são cumpridas as normas estabelecidas, ou seja, os bons costumes. E isso não seria possível sem a construção da interioridade no sujeito, sem a privatização do desejo e a responsabilização dos seus atos. Cada pessoa passa a ser o grande senhor dos seus atos, mas também o grande bandido. A moral dos costumes, bem como os manuais de comportamento, estão na moda nessa época, nas mansões e nos casebres, entre ricos e pobres.

Por mais lamentável que fosse o
amontoamento dos membros da família
em um acanhado reduto, a moral não era
afetada. Vivi ali e jamais ouvi murmurarem
o menor escândalo. Uma vida ativa, hábitos
piedosos, e um pai e uma mãe austeros,
eram coisas que nada permitiam ao
relaxamento dos costumes. (Perrot, 1991, p.
355)

A moral não faz distinção; ela governa, e igualmente pune, quando necessário. A inquisição interioriza-se no século XIX e transforma-se em todo o tipo de má consciência. O personagem, na primeira parte do livro MS, traz essas questões em um nível assustador, a partir de uma consciência hipertrofiada. É um protótipo caricaturado, portanto, do homem do século XIX e de suas mazelas. Não é por acaso que esse primeiro capítulo se chama $O$ subsolo: esse lugar "baixo", "escuro", "úmido", "pantanoso", que somente um rato escolheria de bom grado como sua casa. O interior, agora inventado e cercado pelos muros e pelas grades da casa e da família, é um belo equivalente da interioridade subjetiva. Ambos devem ser vigiados de perto para evitar a invasão do público, do que está fora, do estranho, o primeiro, principalmente pela mulher (a rainha do lar), enquanto o segundo, pela consciência de cada um.

Nesse século, vemos erguer-se, mais forte do que nunca, o Império da moral, esta não mais defendida por algum soberano sobrenatural, como outrora na figura de um Deus ou de um Rei, mas dirigida pelos valores agora 
"Moral e higiene dão-se as mãos como forma de marcar uma diferença entre os nobres e o imundo zépovinho".

Perro† transformados em virtudes individuais. É o século da interiorização da moral.

Já o segundo capítulo do livro MS, A propósito da neve molhada, traz outras peculiaridades com relação ao primeiro. Aqui se trata verdadeiramente de memórias relembradas pelo personagem do (no) subsolo. São relatos de acontecimentos passados, mas, além disso, testemunhos de seus sentimentos mais "íntimos", de sua saúde: "Às vezes, a raiva simplesmente me sufocava. Experimentava sofrimentos sem conta, humilhações e derrames de bílis" (Dostoiévski, 2000, p. 64). A raiva, um dos sintomas do ressentimento, é talvez o principal componente de seus relatos, não qualquer raiva, mas aquela que sufoca, que permanece na consciência enquanto energia reativa.

Como uma seqüência do primeiro capítulo, vemos, nesse segundo, experiências vividas pelo personagem, exemplos de manifestações do ressentimento a partir daquela consciência hipertrofiada de que falamos anteriormente. Se a primeira parte é quase que na sua totalidade racional, a segunda é mais corporal, concreta, ou melhor, nos mostra aquela racionalidade em ação no dia a dia.

Igualmente, esse segundo capítulo mostranos o século XIX a partir de exemplos. É aqui que constatamos a separação entre público e privado bem como a necessidade de representação no espaço público a partir da preocupação com a roupa, com a aparência do corpo, com o modo de andar, de falar, de olhar. A imagem de cada um define também o lugar de cada um, ou o espaço a que cada qual pertence. Ponto de diferenciação, a imagem no espaço público e também no privado serve como forma de dar fruição ao poder e possibilita experimentar a sensação de tornar-se superior e dominar o outro, impulso esse que parece fazer parte de toda a história da humanidade.
O século XIX apenas cria uma outra forma de exercício do poder, mais dissimulado, mas, ainda assim, egoísta, cruel, como podemos perceber neste trecho:

A reconhecida influência do físico sobre o moral valoriza e recomenda o limpo. Novas exigências sensíveis rejuvenescem a civilidade; a acentuada delicadeza das elites, o desejo de manter à distância o dejeto orgânico, que lembra a animalidade, o pecado, a morte, em resumo, os cuidados de purificação aceleram o progresso. Este é estimulado igualmente pela vontade de distinguir-se do imundo zé-povinho (...) Normas extremamente estritas regulam a prática do banho conforme o sexo, a idade, o temperamento e a profissão. (Perrot, 1991, p. 442)

Moral e higiene dão-se as mãos como forma de marcar uma diferença entre os nobres e o imundo zé-povinho. Afastar e separar o diferente de mim, o sujo, a animalidade, o sem valor, eis um dos objetivos da moral do século XIX.

Podemos perceber, portanto, que toda a investida nas novas "descobertas" que esse momento histórico faz sobre os micróbios e as possíveis formas de contágio (por exemplo, dos perigos para a propagação da tuberculose ao dividirmos o mesmo espaço em casa, ou então, com o advento dos vasos sanitários com água corrente, em vez das latrinas), além de terem algum valor para a saúde orgânica, servem também como forma de diferenciação moral e valorização de si em detrimento do outro, formas muito estimadas nesse século. Estar limpo é pertencer a uma casta "superior", e estar sujo é pertencer aos pobres e, portanto, "ser inferior". A higiene íntima é também uma forma de distinção moral, modo muito comum de exercício de poder no século XIX. Aliás, a criação de normas a partir da proliferação de manuais de comportamentos, da higiene, entre tantas outras formas, e, além disso, a não 
necessidade de algum soberano para que essas regras fossem cumpridas caracterizam um novo padrão moral, o que nos leva a pensar que esse "soberano" (que, nos séculos anteriores, eram representados pelas figuras de reis ou mesmo de deuses e, como tal, detinham o poder) ainda existe, porém agora internalizado em forma de valores, sendo a consciência sua guardiã.

Onde existiu vida humana sobre a Terra, existiu necessariamente a norma como condição de possibilidade de existência, portanto, criar normas sempre foi uma indelével característica dos humanos. Onde existiu vida sobre a Terra, existiu necessariamente a vontade de poder (vontade de ter o poder), a vontade de distinção, a vontade de dominar. A moral sempre fora uma ferramenta fundamental para os usos e os prazeres do poder. Entretanto, no século XIX, acentua-se ainda mais sua importância, com o advento de um sujeito interiorizado e consciencioso que encontra nos valores morais o substituto para o Soberano (aquele que decreta as normas) de outros tempos. E é nesse momento que a constituição da memória e dos murmúrios conscientes atinge seu ápice, torna-se um pecado, torna-se ressentimento.

Estamos falando de uma tal "moral do ressentimento", assim chamada e destacada por Nietzsche no livro AFZ.

\section{Assim falou Zaratustra}

Assim como o século XIX, AFZ é um livro paradoxal, e essa característica é levada ao extremo. Com um humor negro cortante e ininterrupto, disseca a moral da decadência (moral cristã). E o que ele observa? Nada! Sim, no fundo dessa moral, não há absolutamente nada de verdadeiro, tudo é inventado, tudo é um malicioso embuste, mentira. Dessa forma, AFZ é um livro que brinca seriamente com o conceito de verdade, com as balizas dos sentimentos, afetos e comportamentos humanos.

Com uma linguagem nada amistosa - uma linguagem guerreira, combatente - Zaratustra eleva um estilo cínico e irônico (assim como o MS) com mistura de palavras sacras, deixando o leitor na dúvida quanto à veracidade daquilo que ele está afirmando. Ora, essa era justamente uma das características do século que estamos estudando: a dissimulação e a aparência. Todavia, a verdade, com Zaratustra, nunca mais gozará da liberdade de outrora, a moral não terá mais a tranqüilidade de antes. O mundo não será mais o mesmo depois dele.

"Entre minhas obras, ocupa o meu Zaratustra um lugar à parte. Com ele fiz à humanidade o maior presente que até agora lhe foi feito" (Nietzsche, 1995, p. 20).

AFZ opera a partir de uma lógica de produção de conhecimento um pouco diferente daquela que, em grande medida, encontramos do século XIX em diante. A começar pela forma, o livro é fragmentado em vários textos com início, meio e fim, chamados de aforismos. Trata-se de um estilo que caracteriza esse autor em praticamente toda a sua produção. Dividido em quatro partes, o Zaratustra nietzscheano compreende uma primeira parte, com 23 aforismos, uma segunda, com 22, uma terceira, com 16, e uma quarta e última parte, com 20 aforismos; no total, 81 aforismos. Tudo isso dá uma noção do quanto ele é um livro fragmentário. Entretanto, não devemos superestimar a independência entre eles, pois é uma característica desse estilo de escrita em que, ao mesmo tempo em que os aforismos gozam de uma certa 
independência por um lado, mantêm-se atrelados por outro.

Quanto ao conteúdo, o livro mescla discursos, diálogos, caminhadas, encontros e cantos, tanto de Zaratustra quanto de outros personagens, mas sempre sob a ótica de Zaratustra. É a narrativa de um trecho da vida do personagem, de seus encontros e desencontros, de suas angústias, de seus medos, e, finalmente, de sua redenção. Uma caminhada por valores morais, que têm como alvo de crítica uma moral decadente observada no século XIX, aproxima em mais um ponto AFZ e MS. Não é um livro contra a moral, mas contra uma moral específica (sem, entretanto, ser pessimista).

No fundo, são duas as negações que a minha palavra imoralista encerra. Eu nego, por um lado, um tipo de homem que até agora foi tido como o mais elevado, os bons, os benévolos, os benéficos; nego, por outro lado, uma espécie de moral que alcançou vigência e domínio como moral em si - a moral da décadence, falando de modo mais tangível, a moral cristã.

(Nietzsche, 1995, p. 111)

Trata-se de uma moral cristã que desejaria o apequenamento do homem, que valorizaria

Não devemos esquecer que o século XIX propaga uma moral tanto anímica como física enquanto verdade suprema, enquanto terque-agir-assim, porque assimdeve-ser. a vontade de poder de ponta-cabeça, voltada contra o próprio homem. AFZ nos apresenta - sob outros ângulos e frestas - a moral da renúncia de si, que, entre outras, apresenta sete armas principais, sete valores, sete pecados.

Assim começa a saga de Zaratustra:

Aos trinta anos de idade, deixou Zaratustra sua terra natal e o lago da sua terra natal e foi para a montanha. Gozou ali, durante dez anos, de seu próprio espírito e da solidão, sem deles se cansar. No fim, contudo, seu coração mudou, e, certa manhã, levantou-se ele com a aurora, foi para diante do sol e assim the falou: "que seria a tua felicidade, ó grande astro, se não tivesses aqueles que iluminas! " (Nietzsche, 2003, p. 33).

Já no primeiro parágrafo do livro, podese perceber seu estilo e seus alvos. A inseparabilidade entre o astro e aquele que ele ilumina é um preâmbulo da crítica à verdade, a tudo aquilo que pretende existir enquanto "coisa em si", enquanto unidade fenomenológica independente do olhar humano. O que Nietzsche não cansa de mostrar - tanto no AFZ como em todas as suas obras - é que as coisas não existem PARA o homem SEM o homem. A verdade, para Nietzsche, longe de "iluminar" e decifrar o mundo, nos revela algo mais fundamental: que tipo de homem é esse que vê e conhece o mundo dessa forma e não de outra? A verdade e os conhecimentos que o homem produz dizem de si, de sua condição histórica, de sua perspectiva de olhar, e não do mundo em si.

Não devemos esquecer que o século XIX propaga uma moral tanto anímica como física enquanto verdade suprema, enquanto terque-agir-assim, porque assim-deve-ser.

As técnicas de contenção destiladas nos conventos penetram então nos meios populares ... despir-se em comum antes de deitar-se no leito fraterno, realizar diante de outros o ritual da toalete, fazer amor no quarto familiar constituem outras tantas condutas que se tornaram "vergonhosas." (Perrot, 1991, pp. 451-452)

Os costumes, os comportamentos, os pensamentos, enfim, todo humano é uma construção, e não algo natural. A maneira de viver está imersa em uma maneira de ver o mundo, em uma moral, é indissociável desta. Mudar os hábitos, os comportamentos, é mudar também a moral, criar outros valores, outras medidas. 


\begin{abstract}
"Talvez se possa ver o Zaratustra inteiro como música; - certamente um renascimento da arte de ouvir era uma precondição para ele" (Nietzsche, 1995, p. 82). E, mais à frente, assinala: "O problema psicológico no tipo do Zaratustra consiste em como aquele que em grau inaudito diz Não, faz Não a tudo a que até então se disse Sim, pode, no entanto, ser o oposto de um espírito de negação" (Nietzsche, 1995, p. 90).

Os dois fragmentos acima apresentam um pouco mais o AFZ. No primeiro, a exigência de um novo ouvir era uma precondição para ele, uma nova maneira de colocar as coisas como condição para que se possa extrair algo de Zaratustra. A primeira e a segunda parte, em especial, dão conta dos fracassos de Zaratustra ao tentar levar sua palavra ao homem, ao lhe falar sobre a morte de Deus e sobre o super-homem. Muitas dificuldades Zaratustra encontrou entre os homens, muitas resistências aos seus ensinamentos. Na verdade, nunca esteve tão sozinho como entre os homens, motivo pelo qual várias vezes ele regressa à sua montanha, para junto de seus animais e da natureza.
\end{abstract}

A terceira parte mostra algumas andanças de Zaratustra, algumas viagens e novamente - assim como em todo o livro - discursos e diálogos com os mais diferentes interlocutores.

2 Esses sete aforismos encontram-se no livro Assim falou Zaratustra (Nietzsche, 2003 pp.288-322), cada qual, em especial como representante de um valor moral a bondade, a conscientização, a penitência, o niilismo, a compaixão, a náusea, a crença voluntária respectivamente. Esses sete valores compõem as bases de uma moral do ressentimento tal como Nietzsche a entende.

A primeira, a segunda e a terceira partes desembocam na importante quarta e última parte, quando Zaratustra, do alto de sua montanha, escuta um grito de socorro e parte ao seu encontro. Nesse movimento, ele vai encontrar sete personagens, que representam sete perigos e sete tentações.

Esses sete encontros compõem aquilo que há de mais nefasto na moral cristã, na moral da decadência (como Nietzsche gostava de chamar), aquilo que diminui mais e mais o homem, aquilo que o arrasta mais fundo para o subsolo, para a negação de si. É o grande teste a que fica submetido Zaratustra, o teste da transvaloração dos valores, pois o que vemos encenado nesses sete encontros são sete valores daquela moral da decadência, sete valores que buscam a sua afirmação na figura daquele que é considerado o mais ímpio de todos: Zaratustra. É o grande enfrentamento, a grande batalha, a grande guerra, e tudo isso no terreno da moral. Aliás, como já havíamos sublinhado anteriormente, a moral, no século XIX, ganha importância enquanto ponto de apoio do poder, constituindo-se a grande detentora dos interesses nesse século. Vemos um reforço dessa hipótese também em Nietzsche, sendo a moral o seu tema predileto e a genealogia da moral um método de análise. Esse método encerra em si uma nova visão, um novo "ouvir" para as questões morais, por um lado, e, por outro, a possibilidade de enfrentamento da moral (dos valores morais) não pela via da negação (niilismo), pelo pessimismo ou romantismo, mas pela via da transvaloração dos valores.

Os sete aforismos que representam as sete tentações a que fica submetido Zaratustra são: Colóquio com os reis, A sanguessuga, $O$ feiticeiro, Sem ofício, O mais feio dos homens, O mendigo voluntário, A sombra ${ }^{2}$.
Narrei poeticamente, como a Tentação de Zaratustra, um momento em que Ihe vem um grito de socorro, em que a compaixão busca surpreendê-lo como um último pecado, subtraí-lo de si mesmo. Permanecer senhor da situação, manter a altura de sua tarefa limpa dos impulsos mais baixos e míopes que agem nas chamadas ações desinteressadas, eis a prova, a última prova, talvez, que um Zaratustra deve prestar - sua verdadeira demonstração de força. (Nietzsche, 1995, p. 29) 


\section{Novos olhares sobre si: a interiorização e a consciência}

O aparecimento do ressentimento no século XIX deve-se a algumas conjunturas sociais e históricas.

A interiorização do sujeito, por um lado, "quanto mais se avança pelo século, mais o apartamento burguês se assemelha, em seu mobiliário, a uma loja de antigüidades onde a acumulação aparece como o único princípio diretor da composição interior do espaço" (Perrot, 1991, p. 335).

\begin{abstract}
A busca de si mesmo é estimulada ainda por todos os fatos históricos que conduzem ao aprofundamento da sensação de identidade. A aceleração da mobilidade social, sobretudo, engendra um sentimento de insegurança. Incita o autor do diário a indagar-se sobre sua posição, a calcular o julgamento dos outros. (Perrot, 1991, pp. 457-458)
\end{abstract}

E o êxtase místico da consciência, por outro:

Sabe-se com quanta audácia os românticos renovaram o imaginário, multiplicaram as pistas do sonho, enriqueceram as modalidades de monólogo interior e convidaram seus leitores à meditação, à contemplação, quando não ao êxtase místico (...) depois de 1830, alargamse os caminhos do imaginário; o devaneio sensorial perde prestígio em benefício do devaneio fabuloso e itinerante que dá livre curso à imaginação... (Perrot, 1991, pp. 467471).

A prática do escrever sobre si (a partir das várias páginas de diários) ganha intensidade no século XIX. Entre outras funções, ela permite que o autor possa pensar sobre si, sobre suas ações e seus comportamentos, como forma de confissão e penitência. O diário vira uma obsessão, uma forma de salvação interior pela palavra, pelo pensamento. As coleções de objetos antigos nos interiores das casas multiplicam-se, as lojas de antiguidades aumentam em número e seus produtos sofrem um acréscimo de valor - econômico e sentimental - significativo. Ter objetos antigos em casa vira sinônimo de distinção burguesa. Esse detalhe da vida privada é bastante sintomático daquilo que acontece em nível pessoal, pois esse século vai gestando rapidamente um interior, ou seja, vai enriquecendo-o com uma infinidade de pensamentos que outrora não faziam parte da consciência. Evidencia-se um verdadeiro êxtase místico da consciência, palco de intermináveis devaneios, cálculos e medidas. Guardar, não esquecer, tornar verdade, tudo isso vira obrigação da consciência e sua própria Verdade, marcando uma distinção de caráter fundamental. Ser consciencioso (colecionador de objetos antigos) é uma distinção pessoal muito valorizada a partir desse século, é ser "burguês", é ser "superior". Possuir um interior rico e povoado permanentemente - movimento reforçado pelas práticas da confissão como forma de obter a salvação da alma pelos pecados do corpo e da mente - é digno de uma casta seleta e especial. O oposto, o pouco pensamento antes da ação, marca um caráter débil, fraco, tosco e próximo do animal. Ser humano, nessa época, é ser consciencioso.

O orgulhoso conhecimento do privilégio
extraordinário da responsabilidade, a
consciência dessa rara liberdade, desse
poder sobre si mesmo e o destino, desceu
nele até sua mais íntima profundeza e
tornou-se instinto, instinto dominante -
como chamará ele a esse instinto dominante,
supondo que necessite de uma palavra
para ele? Mas não há dúvida: esse homem
soberano o chama de sua consciência...
(Nietzsche, 1998, p. 50) A interioridade e a hipertrofia da consciência abrem caminho para uma nova experiência de si. Uma gama infindável de sentimentos, pensamentos e conseqüentes ações ganham espaço na vida individual - e são sentidos como tal. 
O aborrecimento, a suscetibilidade doentia, a impotência de vingança, o desejo, a sede de vingança, o revolver venenos em todo sentido (...) produz um rápido consumo de energia nervosa, um aumento doentio de secreções prejudiciais, de bílis no estômago, por exemplo. O ressentimento é o proibido em si para o doente-seu mal: infelizmente, também sua mais natural inclinação(...) Quem conhece a seriedade com que minha filosofia perseguiu a luta contra os sentimentos de vingança e rancor, até o interior da doutrina do "livre-arbítrio" - a luta contra o cristianismo é apenas um caso particular dela. (Nietzsche, 1995, pp.30-31)

\section{$\mathrm{O}$ ressentimento}

O homem do século XIX passa a habitar o subsolo; na profundidade da sua interioridade (recentemente intensificada), vive toda forma de fantasmas e medos, regras e medidas, culpas e responsabilidades. Um mundo à parte submerge na consciência, provoca calafrios, raivas, ódios, convulsões corporais, histerias, penitências e transformações fisiológicas. A moral do ressentimento atinge a carne, que outrora era ferida pelas fogueiras, pelos enforcamentos e pela guilhotina.

... jamais houve na terra um tal sentimento de desgraça, um mal-estar tão plúmbeo - e, além disso, os velhos instintos não cessaram repentinamente de fazer suas exigências! Mas era difícil, raramente possível, Ihes dar satisfação: no essencial, tiveram de buscar gratificações novas e, digamos, subterrâneas. Todos os instintos que não se descarregam para fora voltamse para dentro - isso é o que chamo de interiorização do homem... (Nietzsche, 1998, p. 73)

O ressentimento se produz nesse escoamento e redirecionamento da crueldade - impedida pelos valores morais de direcionar-se ao outro - para si mesmo.

O ressentimento reina do século XIX em diante, disciplina os corpos, produz vidas.
Diferentemente do modo como a histeria fora compreendida na época e nos séculos que se passaram, ou seja, como uma afecção individual, como um sofrimento que estava ligado à sua vida privada, às suas relações passadas, em uma espécie de ontogênese do desejo do sujeito, propomos um outro olhar a partir do que até aqui refletimos sobre o ressentimento: ele recoloca o sujeito num plano social, já que toda a gama de sentimentos e afetos que o caracterizariam e o tornariam pretensamente ímpar são produzidas por uma moral (portanto social) apenas singularizada pelo sujeito. Nesse sentido, a histeria teria uma ligação direta com a moral, sendo o seu sofrimento um sofrimento de toda uma raça, de todo um tipo de homem.

O ressentimento é esse sinal que nos alerta de que algo vivido subjetivamente se liga a uma moral específica, no caso, à moral do ressentimento, à moral cristã, como a chamamos anteriormente.

Estamos considerando o ressentimento como uma produção social. A sensação de que esse sentimento pertence inexoravelmente ao nosso mundo interior se deve à construção histórica de um ideal de sujeito centrado em si, tendo, inclusive, o ressentimento necessitado dessa arquitetura "interior" para a sua aparição.

O sofrimento vivido individualmente, quando pensado a partir do conceito de ressentimento que estamos constituindo, adquire um caráter social e enfatiza o sofrimento de toda uma cultura, ou seja, o ressentimento nos dá acesso à moral e às suas produções, aos seu efeitos, aos seus valores, às sua possibilidades, às suas Verdades!

Antes direi no ouvido dos psicólogos, supondo que desejem algum dia estudar de perto o ressentimento: hoje essa planta floresce do modo mais esplêndido entre os anarquistas e anti-semitas, aliás, onde 
sempre floresceu, na sombra, como a violeta, embora com outro cheiro. E como do que é igual sempre brotarão iguais, não surpreende ver surgir, precisamente desses círculos, tentativas como já houve bastantes(...) de sacralizar a vingança sob o nome de justiça - como se, no fundo, a justiça fosse apenas uma evolução do sentimento de estar-ferido - e depois promover, com a vingança, todos os afetos reativos. Quanto a esse último ponto, eu não teria em absoluto o que objetar: tendo em vista o problema biológico no seu todo (em relação ao qual o valor desses afetos foi até hoje subestimado), isso me pareceria até mesmo um mérito. (Nietzsche, 1998, pp. 62-63)

Em um momento histórico (séculos XIX XXI) em que tanto se fala em perdas das dimensões sociais pelo sujeito devido a um processo de interiorização do desejo e da visão de si apartada do mundo ilusoriamente "exterior", o estudo do ressentimento parece apontar para uma direção um pouco diferente, embora não oposta: que nunca deixemos de ser sociais, nem mais nem menos, mas apenas de outra forma.

O estudo do ressentimento nos trouxe a idéia de que estamos frente a um sintoma social que se manifesta - e só assim ele pode existir - em uma pessoa, em alguma instituição. Esse sintoma fala de uma moral, de uma cultura, de uma forma de conhecer, de fazer, de um tipo de homem, de uma "raça", e não de uma vida particular (como se desejou que fosse visto todo sofrimento humano a partir do século XIX, ou seja, de forma privada, internalizada). Analisar o ressentimento - seja em alguma clínica, instituição ou mesmo em um trabalho teórico - é analisar a moral, e, portanto, o social.

O processo de individualização - tema bastante teorizado nos séculos posteriores ao XIX - evidenciou um processo de aparente cisão entre público e privado e um voltar-se para si na constituição de uma identidade (de uma subjetividade privatizada). O estudo desse processo em larga escala, sendo para criticá-lo ou mesmo para tomálo como uma representação do que estava se passando em nível subjetivo, encobriu o tema do ressentimento, tornando-o opaco e quase invisível. Cremos que o processo de individualização, construído por vários teóricos como forma de tentar explicar um curioso movimento subjetivo de apequenamento do sujeito para seu próprio mundo "interno" ao longo de vários séculos da era cristã, está até hoje crivado de preconceitos morais:

Uma nova forma de identidade começa a desenhar-se nesse momento; define o indivíduo humano através dos seus pensamentos mais íntimos, das suas imaginações secretas, dos seus sonhos nocturnos, das suas pulsões cheias de pecados, da presença constante, obsessiva, no seu foro íntimo, de todas as formas de tentação. (Dolto et al., 1988)

Por outro ângulo, mas partilhando dessa mesma idéia, Figueiredo nos mostra, a partir da literatura e da Filosofia - principalmente - esse modo de subjetivação individual, de valorização do eu, da intimidade, de 1500 a 1900: “... volta-se para o íntimo, para a privacidade, para as evidências que se dão ao 'olho interior'..." (Figueiredo, 2002, p. 111).

Se, por um lado, podemos destacar um certo modo de subjetivação, de morada, de vivência das experiências individuais que realmente mudam bastante durante a experiência do século XIX, tendo, entre outros fatores constitutivos, a supremacia da moral da introspecção, da moral da confissão, da moral como forma de controle social, da moral cristã, da moral do ressentimento, por outro, a mecânica do ressentimento nos mostrou o quanto esse sintoma ofuscou a sua própria compreensão - o quanto fazia parte do funcionamento do ressentimento 
"fazer-ver" que o sofrimento fosse realmente algo individual, e não social -, sendo o sofrimento humano visto como caso de polícia ou Medicina (por exemplo, o clássico caso de entendimento da mulher histérica no final desse século que, ou era vista como desleixada com as obrigações e deveres femininos e, portanto, responderia judicialmente por isso, ou se tornava caso clínico de interesse médico). Faz parte da engenhosidade do ressentimento impedir que sua ligação aos valores morais seja posta em evidência.

Nossa reflexão até aqui nos leva a pensar que essa "volta ao íntimo" - tão destacada por alguns autores - não é uma volta para a privacidade, mas uma volta à moral (portanto ao social, agora vivido de forma íntima) enquanto instrumento privilegiado de poder sobre as vidas.

Todo olhar sobre a História - e por que não, sobre a invenção do psicológico? - só pode se dar a partir de uma perspectiva que é inerente a todo saber, como nos alertou Foucault:

Os historiadores procuram, na medida do possível, apagar o que pode revelar, em seu saber, o lugar de onde eles olham, o momento em que eles estão, o partido que eles tomam - o incontrolável de sua paixão. O sentido histórico, tal como Nietzsche o entende, sabe que é perspectivo, e não recusa o sistema de sua própria injustiça. (...)Tendo pretendido apagar de seu próprio saber todos os traços do querer, ele reencontrará do lado do objeto a conhecer a forma de um querer eterno. (Foucault, 1979, pp.30-31)

E é nesse sentido que estamos utilizando o ressentimento, para mostrar que, na raiz de todo saber, de todo fazer, de todo compreender, está um querer. E é por isso que ele complementa: "É que o saber não é feito para compreender, ele é feito para cortar" (Foucault, 1979, p. 28). Nesse sentido é que nos parece crivado de preconceitos morais a noção de alguns historiadores que, ao sublinharem o século XIX como momento da interiorização do sujeito e cisão entre indivíduo e social, deram pouca importância à moral e à sua nova configuração.

É necessário mudar a questão para que possamos entender tanto o surgimento desse importantíssimo sintoma (o ressentimento) quanto a silenciosa negligência em relação a ele enquanto tema de estudo nesse momento histórico com o qual estamos trabalhando. Em vez de processo de individualização, não seria interessante pensar que o século XIX produz, paralelamente a esse, um outro processo, um processo de moralização? Já que a mudança evidenciada é - entre outras coisas - uma alteração nas relações de poder que passam a ser exercidas pelos valores morais, e não mais por alguma figura Soberana, e isso, a partir do solo - agora "profundo" - da consciência.

"O fora" (antes reconhecido na figura de Deus ou mesmo na de um Rei ou na de um Estado), o social, ou seja, aquilo que fazia com que algo fosse cumprido pelas diversas instâncias desse social (estando os sujeitos aí inseridos) apenas se transmutou na figura dos valores, tendo estes a importância que tinham aqueles outrora. O alargamento da consciência e o povoamento da memória (a partir de então muito valorizados) que evidenciam um aumento do desejo de guardar o passado, tanto a partir de objetos antigos como a partir das fotografias, no desejo de eternizar, de não esquecer, de naturalizar, criam um solo propício para a propagação do ressentimento e da sensação de que realmente se trata de algo individual.

O ressentimento não só denuncia a negligência até aqui dada à moral enquanto tema de análise como também nos apresenta 
indícios de que parece possível trabalhar com Psicologia social também em nível pessoal, ou seja, com algo social (a moral do ressentimento) singularmente.

Não é um processo de individuação, tão somente, o que pudemos observar até aqui (como tentamos mostrar a partir da contribuição de alguns autores anteriormente) mas também um processo de moralização. Este último não é essencialmente social, mas social-moral, e não social-individual. Somos tão sociais hoje como fomos em outras épocas, apenas de uma outra forma. A ênfase aqui é no social, e não no individual, sendo que o processo de individuação (enquanto forma privilegiada de conceber o homem do século XIX em diante) parece não ter passado de uma ilusão com estratégias e efeitos bem definidos, qual seja, o de evitar que a moral (ferramenta importante de uso do poder a partir desse instante) fosse vista em ação. Todavia, não pôde evitar a aparição de seu nefasto sintoma, o ressentimento, que o denunciou.

O olhar que antes se dirigia a um pretenso interior da alma na busca de desejos disfarçados, agora - a partir do ressentimento - repousa sobre os valores que agitam a vida do sujeito; é, portanto, plenamente social, pois não há nada mais social do que os valores morais de uma época.

Não somente o mau, mas principalmente o bom necessita ser desbanalizado. Dessa forma, quem estará em psicoterapia na nossa frente, em nossos consultórios, não será mais o sujeito, mas uma raça, os modos arcaicos de vida, as verdades milenares, os monumentos sagrados, enfim, uma moral.

Pensar sobre a subjetividade hoje a partir de tudo o que dissemos sobre o ressentimento nos deixa não uma resposta, mas um outro problema: a Psicologia inclinou-se até hoje, em grande medida, sobre os sintomas do homem; entretanto, poderá ser interessante, e até louvável - quem sabe? - tomar o homem como um sintoma? Isso corresponderia a problematizar o homem que cria os sintomas do homem e a produzir nesse esforço uma clínica irremediavelmente envolvida com o aspecto social. 


\section{Marisa Faermann Elsirik}

Doutora em Educação/UFRGS; Professora da Pós-Graduação em Psicologia Social e Institucional/UFRGS.

E-mail: meizirik.ez@terra.com.br

\section{Juliano Fontana Trevisan}

Psicólogo, formado pela UFSM

Mestre em Psicologia Social e Institucional/UFRGS.

E-mail: psicologo_ft@yahoo.com.br

Endereço para correspondência:

Ramiro Barcelos, 2.600 Cep 90035-003, Porto Alegre-RS

Dolto, F., Verela, F., Percheron, G., Veyne, P., Dumont, L., Ricoeur, P., \& Vernant, J.-P. (1988). Indivíduo e poder. Portugal: Edições 70.

Dostoiévski, F. (2000). Memórias do subsolo. (3ª ed.). São Paulo: 34

Eizirik, M. (2002). Michel Foucault: um pensador do presente. ljuí RS:Unijuí.

Figueiredo, L. C. M. (2002). A invenção do psicológico: quatro séculos de subjetivação (1500 - 1900). (6a ed.). São Paulo: Escuta.

Foucault, M. (1979). Microfísica do poder. Rio de Janeiro: Graal.
Giacoia, O. (2001). Nietzsche como psicólogo. São Leopoldo RS: Ed. Unisinos.

Nietzsche, F. (1995). Ecce homo: como alguém se torna o que é. São Paulo: Companhia das Letras.

Nietzsche, F. (1998). Genealogia da moral: uma polêmica. São Paulo: Companhia das Letras.

Nietzsche, F. (2003). Assim falou Zaratustra: um livro para todos e para ninguém.(12a ed.). Rio de Janeiro: Civilização Brasileira.

Perrot, M. (1991). História da vida privada, Vol. 4: Da Revolução Francesa à Primeira Guerra. São Paulo: Companhia das Letras. 